\title{
HUBUNGAN BEBAN KERJA PERAWAT DENGAN TINGKAT KEPUASAN PASIEN DALAM PEMBERIAN ASUHAN KEPERAWATAN DI RUANG RAWAT INAP RSU GMIM PANCARAN KASIH MANADO
}

\author{
Yolanda Maweikere ${ }^{a}$, Aaltje Ellen Manampiring ${ }^{b}$, Juwita M. Toar \\ a-cProgram Studi Ilmu Keperawatan Fakultas Kedokteran Universitas Sam Ratulangi \\ Corresponding authorl: ns.juwita@unsrat.ac.id
}

\begin{abstract}
Nursing as a professional service is an integral part that cannot be separated from the overall health care efforts. The quality nursing service is a determining factor in the level of patient satisfaction. The high demands of the community for nursing services can be unconsciously lead to workloads for nurses. The aim of this study is finding the corelation between the workload of nurses and the level of patient satisfaction in providing nursing care in the patient ward of the RSU GMIM Pancaran Kasih Manado. The design of the research was descriptive analytic with a cross sectional study approach. Samples of 42 nurses and 42 patients were obtained using a total sampling technique. The results of statistical research using the Chi-square test at a significance level of 95\%, obtained a significant value $\rho=$ $0.000<\alpha(0.05)$. There is a corelation between the workload of nurses and the level of patient satisfaction. The suggestions especially for the nurses are policy of managing health personnel, establish and firm job descriptions for each nurse in the hospital.
\end{abstract}

Keywords : workload, patient satisfaction, Nurse

\begin{abstract}
Abstrak
Keperawatan sebagai bentuk pelayanan profesional merupakan bagian integral yang tidak dapat dipisahkan dari upaya pelayanan kesehatan secara menyeluruh. Pelayanan keperawatan yang berkualitas menjadi faktor penentu tingkat kepuasan pasien. Tuntutan yang tinggi dari masyarakat akan pelayanan keperawatan secara tidak disadari dapat menimbulkan suatu beban kerja bagi perawat. Tujuan penelitian ini adalah untuk mengetahui hubungan beban kerja perawat dengan tingkat kepuasan pasien dalam pemberian asuhan keperawatan di ruang rawat inap RSU GMIM Pancaran Kasih Manado. Desain penelitian yang digunakan yaitu Deskriptif Analitik dengan pendekatan Cross Sectional Study. Sampel berjumlah 42 Perawat dan 42 Pasien yang didapat dengan menggunakan tehnik Total Sampling. Hasil penelitian uji statistik menggunakan uji Chi-square pada tingkat kemaknaan 95\%, didapatkan nilai signifikan $\rho=0,000<\alpha(0,05)$. Kesimpulan ada hubungan antara beban kerja perawat dengan tingkat kepuasan pasien. Saran dalam kebijakan pengelolaan tenaga kesehatan, khususnya perawat untuk dapat menetapkan pembagian tugas yang jelas dan tegas pada tiaptiap perawat di rumah sakit.
\end{abstract}

Kata kunci : beban kerja, kepuasan pasien, Perawat 


\section{PENDAHULUAN}

Keperawatan sebagai bentuk pelayanan profesional merupakan bagian integral yang tidak dapat dipisahkan dari upaya pelayanan kesehatan secara menyeluruh. Di rumah sakit, pelayanan keperawatan mempunyai posisi yang sangat strategis dalam menentukan mutu pelayanan karena jumlah perawat terbanyak dari profesi lain dan paling lama kontak dengan klien. Dengan demikian, maka keperawatan adalah ujung tombak pelayanan kesehatan dan sering digunakan sebagai indikator kualitas pelayanan kesehatan yang bermutu, serta berperan dalam menentukan tingkat kepuasan klien (Yuniarti, 2012). Pelayanan keperawatan yang berkualitas menjadi faktor penentu tingkat kepuasan pasien. Sehingga hal itu berpengaruh terhadap kulitas pelayanan di rumah sakit, dan kulitas pelayanan tersebut merupakan satu indikator yang menentukan kepuasan pasien (Butar-butar \& Simamora, 2016).

Tuntutan yang tinggi dari masyarakat akan pelayanan keperawatan secara tidak disadari dapat menimbulkan suatu beban kerja bagi perawat pada saat melaksanakan tugasnya. Beban kerja ini tidak nampak dari luar, tetapi sangat mempengaruhi kinerja perawat dalam mengemban tugasnya, sehingga hal ini dapat secara langsung mempengaruhi pula tingkat kepuasan pasien (Werdani, 2016). Masalah beban kerja perawat memiliki dampak yang luas sehingga harus menjadi perhatian bagi institusi pelayanan kesehatan terlebih bagi profesi perawat. Beban kerja perawat yang tinggi dapat menyebabkan penurunan kinerja perawat dan kurang atau buruknya komunikasi antara pasien dan perawat, berpengaruh terhadap kondisi pasien, sehingga berdampak pada buruknya mutu pelayanan keperawatan (Saputra, 2016).

Perawat dilaporkan mengalami beban kerja yang berat di sejumlah negara Asia Tenggara, seperti Malaysia, Thailand, dan Indonesia. Beban kerja yang berat dialami perawat dikarenakan menghadapi keterbatasan waktu dalam mengerjakan tugas, banyaknya pekerjaan yang harus dilakukan (perawatan dan non perawatan), dan tingginya tingkat kompleksitas pekerjaan ataupun perawatan pasien yang dikerjakan serta rasio perawat berbanding penduduk sebesar 1:329 (Saputra, 2016).

Perawat juga menghadapi beban kerja yang tinggi di Indonesia karena selain banyaknya tugas di luar tugas utamanya, juga dikarenakan oleh kurangnya jumlah perawat dimana perbandingan rasio perawat dan penduduk adalah 94 berbanding 100.000 serta distribusi perawat di sejumlah daerah yang tidak merata, sehingga seorang perawat harus melayani banyak pasien dalam satu waktu. Hal ini menyebabkan beban kerja yang dirasakan perawat pun menjadi tinggi (Saputra, 2016).

Bila perawat memiliki beban kerja yang tinggi, maka dapat memberikan pengaruh yang besar terhadap pemberian asuhan keperawatan yang diberikan kepada pasien dan keluarganya, sehingga tingkat kepuasan pasien terhadap pemberian asuhan keperawatan keperawatan mungkin saja dapat mengalami penurunan. Tingkat kepuasan pasien merupakan indikator dari mutu sebuah pelayanan RS, sehingga jika banyak pasien/ keluarga yang tidak puas akan pelayanan keperawatan yang diberikan, maka akan berdampak terhadap ketidakloyalan customer, dan dalam jangka waktu yang panjang akan menurunkan persentase Bed Occupation Rate (BOR) dari RS tersebut, namun sebaliknya semakin besar persentase kepuasan dari penerima jasa pelayanan, maka RS akan menjadi tempat rujukan utama bagi masyarakat dalam meminta pertolongan kesehatan (Werdani, 2016).

Ketidakpuasan pasien terhadap pelayanan keperawatan baik di Indonesia maupun di negara berkembang lainnya saat ini masih menjadi masalah. Data kepuasan pasien di salah satu rumah sakit umum daerah di 
Indonesia didapatkan $70 \%$ pasien kurang puas terhadap pelayanan keperawatan (Widiasari, 2019). Data di rumah sakit salah satu negara ASEAN pada tahun 2016 didapatkan bahwa kepuasan pasien $79 \%$, sedangkan standar yang ditetapkan kepuasan pasien $>80 \%$ dengan angka komplain 4-5 kasus/bulan (Widiasari, 2019).

Kepuasan pasien merupakan suatu tingkat perasaan dari pasien yang timbul akibat dari kinerja layanan kesehatan yang diperoleh setelah membandingkan dengan apa yang diharapkannya, yang dipengaruhi oleh faktor usia, jenis kelamin, dan latar belakang pendidikan. Individu yang berusia lebih tua cenderung menunjukan tingkat kepuasan lebih tinggi dibandingkan pasien berusia lebih muda karena mereka yang berusia lebih tua cenderung menerima dan bijaksana dalam menanggapi permasalahan (Pohan, 2006).

Hasil studi pendahuluan di ruang rawat inap RSU GMIM Pancaran Kasih Manado di tiga ruangan perawatan rawat inap (Hana, Lukas, Yehezkiel) menunjukkan ruang rawat inap 3 ruangan tersebut memiliki jumlah bed dengan kapasitas tempat tidur sebanyak 70 dan minimal terisi 50 pasien setiap harinya. Jumlah perawat di 3 ruang tersebut berjumlah 42 orang dimana di setiap ruangan pada shift pagi sejumlah 3 orang, shift sore 2 orang, dan shift malam 3 orang. Hal tersebut belum sesuai dengan standar yang direkomendasikan. Kebutuhan tenaga perawat yang direkomendasikan berdasarkan perhitungan dengan rumus Douglas adalah 4 orang pada shift pagi, 3 orang pada shift sore, dan 4 orang pada shift malam. Peraturan Menteri Kesehatan No. 56 Tahun 2014 tentang Klasifikasi dan Perizinan Rumah Sakit menyebutkan bahwa perbandingan rasio tempat tidur : tenaga perawat untuk rumah sakit tipe C adalah 3:2 (Menkes, 2014). Seringkali terdengar keluhan dari beberapa perawat tentang jadwal shift atau lembur yang tidak menentu dan beban kerja yang cukup tinggi dirasakan oleh perawat terjadi pada shift sore (2 perawat) dan malam hari (2-3 perawat) sehingga jumlah perawat tidak sebanding dengan jumlah pasien, dengan demikian beban kerja perawat pun meningkat sehingga dapat mempengaruhi kepuasan pasien dalam menerima asuhan keperawatan.

Berdasarkan fenomena yang ada peneliti tertarik untuk melakukan penelitian tentang "Hubungan Beban Kerja Perawat Dengan Tingkat Kepuasan Pasien dalam pemberian asuhan keperawatan di ruang rawat inap RSU GMIM Pancaran Kasih Manado".

\section{METODE}

Penelitian ini termasuk dalam jenis penelitian kuantitatif dengan menganalisis gambaran hubungan antara kedua variabel yaitu variabel independen (Beban Kerja) dan variabel dependen (Kepuasan Pasien). Penelitian ini menggunakan desain penelitian cross sectional. Penelitian ini dilaksanakan di RSU GMIM Pancaran Kasih Manado pada bulan OktoberDesember 2020. Populasi dalam penelitian ini adalah perawat di ruang rawat inap RSU GMIM Pancaran Kasih Manado di ruangan Hana, Lukas, Yeheskiel dan pasien berdasarkan jumlah kapasitas tempat tidur yang ada di rawat inap Ruangan Hana, Lukas dan Yeheskiel totalnya ada 70 tempat tidur. Pengambilan sampel menggunakan teknik total sampling. Instrumen penelitian yang digunakan untuk mengukur variabel beban kerja menggunakan kuesioner yang digunakan sebelumnya oleh Hutagaol (2013), Pengukuran Kepuasan Pasien menggunakan kuesioner yang di gunakan sebelumnya oleh Sjaman (2018).

Pengolahan data yang diperoleh dari hasil penelitian ini diolah dan dianalisis menggunakan uji statistik melalui sistem komuterisasi dengan beberapa tahap yaitu editing, coding, cleaning, tabulating 
(Notoatmodjo, 2010). Analisa bivariat dalam penelitian ini yaitu untuk mengetahui hubungan antara beban kerja perawat dengan tingkat kepuasan pasien di
RSU GMIM Pancaran Kasih Manado. Peneliti menggunakan uji statistic Chi Square dengan tingkat kemaknaan 95\% ( $\alpha$ $=0,05)$.

\section{HASIL}

\section{Karakteristik Responden}

Tabel 1. Distribusi Responden Berdasarkan Beban Kerja

\begin{tabular}{ccc}
\hline Beban Kerja & n & \% \\
\hline Ringan & 29 & 69,0 \\
Berat & 13 & 31,0 \\
\hline Total & $\mathbf{4 2}$ & $\mathbf{1 0 0}$ \\
\hline
\end{tabular}

Hasil penelitian yang dilakukan di RSU GMIM Pancaran Kasih Manado dengan jumlah responden 42 orang, sebanyak 29 orang $(69,0 \%)$ memiliki beban kerja yang
Ringan. Sedangkan 13 responden $(31,9 \%)$ dalam kategori berat.

Tabel 2. Distribusi Responden Berdasarkan Kepuasan Pasien

\begin{tabular}{ccc}
\hline Kepuasan Pasien & n & \% \\
\hline Puas & 28 & 66,7 \\
Tidak Puas & 14 & 33,3 \\
\hline Total & $\mathbf{4 2}$ & $\mathbf{1 0 0}$ \\
\hline
\end{tabular}

Penelitian yang dilakukan di RSU GMIM Pancaran Kasih Manado dengan jumlah responden 42 pasien, sebanyak 28 orang $(66,7 \%)$ sangat puas. Dan 14 responden $(33,3 \%)$ tidak puas. Hal ini menandakan pelayanan keperawatan yang ada di RSU GMIM Pancaran Kasih Manado sudah sangat baik dengan adanya hasil penelitian yang menunjukan kepuasan dari pasien.

\section{Analisa Bivariat}

Tabel 3. Hubungan Beban Kerja Perawat Dengan Tingkat Kepuasan Pasien

\begin{tabular}{cccccccc}
\hline Beban Kerja & \multicolumn{4}{c}{ Kepuasan Pasien } & & Total & P \\
\cline { 2 - 5 } & \multicolumn{2}{c}{ Tidak Puas } & Puas & & & \\
\cline { 2 - 6 } & $\mathrm{n}$ & $\%$ & $\mathrm{n}$ & $\%$ & $\mathrm{n}$ & $\%$ \\
\hline Ringan & 3 & 10,3 & 26 & 89,7 & 29 & 100,0 & \multirow{2}{*}{0,000} \\
\hline Berat & 11 & 84,6 & 2 & 15,4 & 13 & 100,0 & \\
\hline Total & $\mathbf{1 4}$ & $\mathbf{3 3 , 3}$ & $\mathbf{2 8}$ & $\mathbf{6 6 , 7}$ & $\mathbf{4 2}$ & $\mathbf{1 0 0 , 0}$
\end{tabular}

Hasil penelitian terhadap 42 perawat dan 42 pasien di dapatkan hasil hubungan antara Beban kerja dengan tingkat kepuasan pasien dengan hasil beban kerja yang ringan dengan tingkat kepuasan pasien tidak puas sebanyak 3 responden. Dengan hasil uji statistik di peroleh nilai $\rho$ $=0,000$ maka dapat disimpulkan bahwa 
ada Hubungan Beban Kerja Perawat Dengan Tingkat Kepuasan Pasien Dalam Pemberian Asuhan Keperawatan. Hal ini menandakan bahwa beban kerja yang di miliki perawat yang ada di RSU GMIM Pancaran Kasih Manado ringan, sehingga kepuasan yang di dapatkan oleh pasien sangat puas.

\section{PEMBAHASAN}

Dari hasil penelitian didapatkan sebagian besar responden yaitu 29 orang $(69,0 \%)$ memiliki beban kerja yang Ringan dan sisanya dalam kategori berat. Hal ini menandakan bahwa beban kerja perawat dalam keadaan yang baik karena memiliki beban kerja yang ringan. Hal ini di buktikan dengan jawaban responden di dalam kuesioner yang menjawab tidak pernah merasa jenuh dalam berikap ramah dan tidak pernah merasa pasien datang terlalu banyak. Analisa beban kerja perawat dapat dilihat dari aspek-aspek seperti tugas-tugas yang dijalankan berdasarkan fungsi utama dan tugas tambahan yang dikerjakan, jumlah pasien yang harus dirawat, kapasitas kerjanya sesuai dengan pendidikan yang diperoleh, waktu kerja yang digunakan untuk mengerjakan tugasnya sesuai dengan jam kerja yang berlangsung setiap hari, serta kelengkapan fasilitas yang dapat membantu perawat menyelesaikan kerjanya dengan baik (Kurniati, 2013).

Kepuasan pasien merupakan perasaan yang dimiliki pasien dan timbul sebagai hasil dari kinerja layanan kesehatan setelah pasien membandingkannya dengan apa yang diharapkan (Pohan, 2006). Hasil tersebut berupa respon dari pasien terhadap pelayanan kesehatan yang diterima secara nyata. Pelayanan kesehatan yang dimaksud dalam penelitian ini yakni kepuasan pasien dalam pelayanan keperawatan. Kepuasan pasien adalah suatu prioritas yang akan membantu perawat dalam memberikan pelayanan keperawatan agar pasien mau berparisipasi selama perawatan.
Kepuasan pelanggan (pasien) terjadi apabila apa yang menjadi kebutuhan, keinginan, atau harapannya dapat terpenuhi. Harapan tersebut dapat terpenuhi melalui jasa (pelayanan kesehatan) yang diterima olehnya. Oleh karena itu kepuasan pasien adalah selisih (gap) antara layanan yang diterima oleh pasien dengan harapan pasien pada layanan tersebut (Supranto,2011).

Hasil penbelitian menunjukkan 13 responden mengungkapkan beban kerja berat. Hal yang membuat beban kerja berat pada perawat di Ruangan Perawatan RSU GMIM Pancaran Kasih Manado adalah belum maksimalnya pengaturan tenaga berdasarkan tingkat ketergantungan pasien yang dirawat dan ditambah dengan tugas perawatan yang tak langsung atau pekerjaan yang tidak berhubungan dengan pemenuhan kebutuhan pasien baik fisik, psikologis, sosial dan spiritual yaitu seperti membuat rencana perawat, menyiapkan alat, konsultasi dengan angggota tim, menulis dan membaca catatan kesehatan dan melaporkan kondisi pasien sehingga akan banyak tindakan yang dilakukan.

Pada penelitian ini juga ditemukan adanya hubungan Beban Kerja Perawat Dengan Tingkat Kepuasan Pasien Dalam Pemberian Asuhan Keperawatan. Menurut Revans dalam Izzah, Sriatmi, \& Wigati (2014), pasien yang masuk pada pelayanan rawat inap akan mendapatkan beberapa pelayanan yaitu pelayanan dokter, pelayanan perawat, pelayanan fasilitas penunjang medik, lingkungan langsung pasien serta pelayanan administrasi.

Kepuasan pasien menjadi bagian yang integral dan menyeluruh dari kegiatan jaminan mutu pelayanan kesehatan. Artinya, pengukuran tingkat kepuasan pasien harus menjadi kegiatan yang tidak dapat dipisahkan dari pengukuran mutu pelayanan kesehatan, sehingga kepuasan pasien tidak lepas dari pelayanan keperawatan yang di berikan perawat di dalam rumah sakit yang tidak lepas dari 
beban kerja perawat. Data hasil penelitian yang diperoleh, sesuai dengan konsep yang menerangkan hubungan positif antara beban kerja dengan kepuasan Pasien. Yuniarti (2012), menyatakan bahwa beban kerja berpengaruh negatif terhadap kepuasan Pasien. Beban kerja yang tinggi memiliki pengaruh yang negatif terhadap kepuasan yang di dapatkan oleh pasien.

Dalam penelitian ini juga di dapatkan 11 orang $(84,6 \%)$ perawat memiliki beban kerja yang berat. Hal ini sejalan dengan pendapat Yuniarti (2012), bahwa kepuasan adalah kinerja yang dirasakan dengan harapan, apabila kinerja perawat dibawah harapan, maka pasien akan kecewa, bila kinerjasesuai harapan pasien akan puas dan bila kinerja melebihi harapan pasien akan sangat puas. Menurut peneliti, beban kerja terasa berat bila tidak diimbangi dengan jumlah tenaga yang sesuai, uraian tugas yang tidak jelas, dan tidak diimbangi dengan penambahan ilmu dan keterampilan yang berkesinambungan.

Kepuasan pasien dan beban kerja perawat merupakan suatu hal yang penting dalam menentukan perilaku dan respon terhadap pekerjaan dan pelayanan keperawatan yang di berikan kepada setiap pasien yang datang ke rumah sakit. Hasil penelitian ini juga menyempurnakan teori bahwa adanya kepuasan dari pelanggan atau pasien yang menjadi motivator perawat untuk bekerja serta rasa kekeluargaan di lingkungan kerja yang menjadikan beban kerja seorang perawat menjadi baik (Muhadi, 2012).

\section{KESIMPULAN}

Beban Kerja dari seorang perawat mempengaruhi kepuasan dari pasien yang menerima perawatan. Di buktikan dari hasil penelitian yang menunjukan pasien sangat puas dengan pelayanan keperawatan.

\section{DAFTAR PUSTAKA}

Butar-butar, J., \& Simamora, R. H. (2016). Hubungan Mutu Pelayanan
Keperawatan dengan Tingkat Kepuasan Pasien Rawat Inap di RSUD Pandan Kabupaten Tapanuli Tengah. Jurnal Ners Indonesia

Dian, W., D. (2013). Hubungan Layanan Keperawatan Dengan Tingkat Kepuasan Pasien Rawat Inap Di Puskesmas Sumbersari Kabupaten Jember

Erawan, A. (2012). Hubungan Beban Kerja Perawat dengan Empati Perawat di Ruang Rawat Inap Medikal Bedah RSUP Dr. Soeradji Tirtonegoro Klaten.

Hutagaol, Henni. (2013). Hubungan Beban Kerja Dengan Stress Kerja Perawat di IGD RSAB Harapan Kita. Universitas Esa Unggul

Izzah, N. N., Sriatmi, A., \& Wigati, P. A. (2014). Analisis Perbedaan Tingkat Kepuasan Pasien Umum dan Pasien Jamkesmas Terhadap Pelayanan Dokter Pada Unit Rawat Inap Di Puskesmas Mlonggo Kabupaten Jepara. e-jurnal Kesehatan Masyarakat

Kurniati. (2013). Kepuasan Pasien Rawat Inap Lontora Kelas III Terhadap Pelayanan Kesehatan di Rumah Sakit Wahidin Sudirohusodo Makasar. Universitas Hasanuddin

Muhadi. (2012). Kepuasan kerja dan Beban kerja.

Mustapha, Noraani dan Ghee, W, Y. (2013). Examining Faculty Workload as Antencedent of Job Satisfaction among Academic Staff of Higher Public Education on Kelantan Malaysia. Journal Business and Management Horizons

Notoadmodjo, S. (2010). Metodologi penelitian kesehatan. Jakarta: Rineka Cipta

Oini, Omy. (2017). Tingkat Kepuasan Pasien Terhadap Pelayanan Keperawatan Di Unit Rawat Inap. Universitas Pelita Harapan 
Pohan, I. (2006). Jaminan Mutu Layanan Kesehatan Dasar-dasar Pengertian dan Penerapan. Jakarta: EGC

Riyanto, Yatim.(2011). Metodologi Penelitian Pendidikan. Surabaya: SIC

Saputra, Rendra. (2016). Hubungan Beban Kerja Perawat Dengan Mutu Pelayanan Keperawatan Di Rawat Inap Rumah Sakit Umum Daerah Sultan Syarif Mohamad AlkadrieKota Pontianak. Universitas Tanjungpura

Sjaman, Ichwan. (2018). Kepuasan Pasien Tehadap Pelayanan Keperawatan di Ruang Ayub 3 Rumah Sakit Roemani Semarang

Supranto. (2011). Pengukuran Tingkat kepuasan Pelanggan. Jakarta: Rineka Cipta

Werdani, Yesiana. (2016). Pengaruh Beban Kerja Mental Perawat Terhadap Tingkat Kepuasan Pasien Di Ruang Rawat Inap Rumah Sakit Swasta Di Surabaya. Universitas Katolik Widya Mandala Surabaya

Widiasari. (2019). Kepuasan Pasien Terhadap Penerapan Keselamatan Pasien Di Rumah Sakit. Universitas Indonesia

Wulandari, Nofianti. (2015). Hubungan Layanan Keperawatan Dengan Tingkat Kepuasan Pasien Rawat Inap di Rumah Sakit Umum Daerah Ungaran Semarang. Universitas Negeri Semarang

Yuniarti, Siswari. (2012). Hubungan Beban Kerja Perawat Dengan Tingkat Kepuasan Pasien Terhadap Pelayanan Keperawatan. Poltekkes Kemenkes Surabaya 